\section{Evolution of Resistance to Gas Diffusion during Cherimoya (Annona cherimola Mill.) Ripening}

\author{
G. Martínez, M.T. Pretel, M. Serrano, and F. Riquelme \\ Centro de Edafología y Biología Aplicada del Segura, Avenida La Fama 1, \\ Murcia 30003, Spain
}

Additional index words. ripening, ethane

Abstract. Resistance (R) to preloaded gas diffusion was used to follow the evolution of $\mathbf{R}$ during cherimoya fruit maturation and senescence. Cherimoya ethane diffusion was linear and gave an $R$ value of $2048 \pm 167 \mathrm{~s}^{\cdot} \mathrm{cm}^{-1}$ for preclimacteric fruit. $R$ increased linearly during maturation, and significant differences were noted between fruit in which diffusion through the stem scar was or was not blocked with petroleum ielly.
The gas exchange that takes place between plant cells and their surrounding atmosphere is a steady-state system regulated by metabolic activity, membrane and coating resistance, and the composition of the atmosphere surrounding the fruit or vegetable. Internal atmospheres can be determined directly in products with cavities or by subjecting products immersed in water to a vacuum to extract gas in intercellular spaces (Salveit, 1982). These atmospheres also can be analyzed indirectly by measuring the resistance to gas diffusion $(\mathrm{R})$ through the tissues and epidermis that constitute various plant organs.

We concur with Burg and Burg (1965) and Cameron and Yang (1982) that the skin is much shallower than fruit diameter, that diffusion in the flesh (internal tissues) is much more rapid than in the skin, and that the concentration of the preloaded gas in fruit is much greater than that in the container in which measurements are taken. Under these conditions, gas exchange between fruit and their surroundings can be estimated with Fick's First Law (Burton, 1978), which establishes the dependence on the concentration gradient and diffusion coefficient. Based on this law, the method described by Cameron and Yang (1982) to determine diffusion coefficients in plant tissues uses a kinetic analysis of the efflux of preloaded ethane gas. The concentration of ethane as a function of time $[\mathrm{dCe}(\mathrm{t})]$ is determined by $\mathrm{dCe}(\mathrm{t}) / \mathrm{dt}=\mathrm{A} / \mathrm{R} \times \mathrm{Vi}[\mathrm{Ce}(\infty)$ $-\mathrm{Ce}(\mathrm{t})]$, where $\mathrm{Ce}(\mathrm{t})=$ ethane concentration in the container at time $\mathrm{t}\left(\mathrm{mm}^{3} \cdot \mathrm{dm}^{-3}\right) ; \mathrm{t}=$ time

Received for publication 31 Oct. 1991. Accepted for publication 19 Oct. 1992 . We are grateful to the Comisión de Ciencia y Techología (Project ALI-880256-CO202) for financial support. We also are indebted to I. Montoya, I. Moratilla, and C. Saura for their cooperation in the experiments involved in the present study. The cost of publishing this paper was defrayed in part by the payment of page charges. Under postal regulations, this paper therefore must be hereby marked advertisement solely to indicate this fact. (sec); $\mathrm{A}=$ fruit surface area $\left(\mathrm{cm}^{2}\right) ; \mathrm{R}=$ fruit surface resistance to gas diffusion $\left(\mathrm{s} \cdot \mathrm{cm}^{-1}\right) ; \mathrm{Vi}$ $=$ volume inside the tissue accessible to ethane $\left(\mathrm{cm}^{3}\right)$; and $\mathrm{Ce}(\infty)=$ container's ethane concentration $\left(\mathrm{mm}^{3} \cdot \mathrm{dm}^{-3}\right)$ after complete equilibration.

Plotting the value of $-\ln [1-\mathrm{Ce}(\mathrm{t}) / \mathrm{Ce}(\mathrm{w})]$ against time estimates $\mathrm{R}$ as $\mathrm{R}=\mathrm{A} / \mathrm{B} \times \mathrm{Vi}$, where $\mathrm{B}=\mathrm{A} / \mathrm{R} \times \mathrm{Vi}$ (slope of the curve).

Banks (1985) used the same model, but transformed the exponential model into a linear one by taking gas samples at 10 -sec intervals for $100 \mathrm{sec}$. In this way, efflux intensity was expressed by $\mathrm{Ci}(0)$ and $\mathrm{R}$ was estimated from the plot of $\mathrm{Ce}(\mathrm{t})$ against $\mathrm{t}: \mathrm{R}=\mathrm{Ci}(0) \times \mathrm{A} / \mathrm{Ve} \times$ $\mathrm{dCe} / \mathrm{dt}$, where $\mathrm{Ci}(0)=$ internal ethane concentration at $\mathrm{t}=0$, and $\mathrm{Ve}=$ external volume equal to container volume minus fruit volume $\left(\mathrm{cm}^{3}\right)$.

We studied cherimoya fruit $\mathrm{R}$ to preloaded gas and determined which of the above methods best described evolution of $\mathrm{R}$ during fruit maturation and senescence. vested from Almuñecar (Granada) 1 day before being transferred to the laboratory. They were selected for size and shape uniformity and for ethylene emission rate as an indication of their degree of ripeness. During the experiments, they were stored at $20 \pm 1 \mathrm{C}$ and $70 \% \pm 5 \%$ relative humidity. In each experiment, fruit were divided into two groups: controls and those in which the stem scar was covered with petroleum jelly.

We chose ethane for the preloading experiments because it has properties similar to those of ethylene, is produced in small quantities in fruit (Kuo and Parkin, 1989), and is not metabolized. Cherimoya's low fat content $(<0.5 \%)$ (Sherz et al., 1986) would preclude any significant loss of the gas into the lipids (Solomos, 1987); we therefore assumed that the gas was totally soluble in cellular sap. Ethane efflux intensity was measured in five fruit per experiment. The fruit were placed in 10-liter jars and purged with a continuous flow of air containing $1000 \mu 1$ of ethane/liter for 8 $h$ to enable fruit internal atmosphere to equilibrate with ethane atmosphere. To measure diffusion, we transferred each fruit to a second ethane-free jar (3.5 liter) containing a diaphragm pump that could be activated externally to ensure rapid gas mixing inside the jar.

To determine ethane and ethylene concentration, 1-ml gas samples from the jars were taken at regular intervals and quantified in a gas chromatograph (model 5890; HewlettPackard, Pennsylvania) equipped with a flame ionization detector and a stainless steel column, $3 \mathrm{~m} \times 3.175 \mathrm{~mm}$, filled with $80 / 100$ mesh activated alumina. Each gas sample was sealed until analyzed by inserting the syringe needle
'Fino de Jete' cherimoya fruit were har-

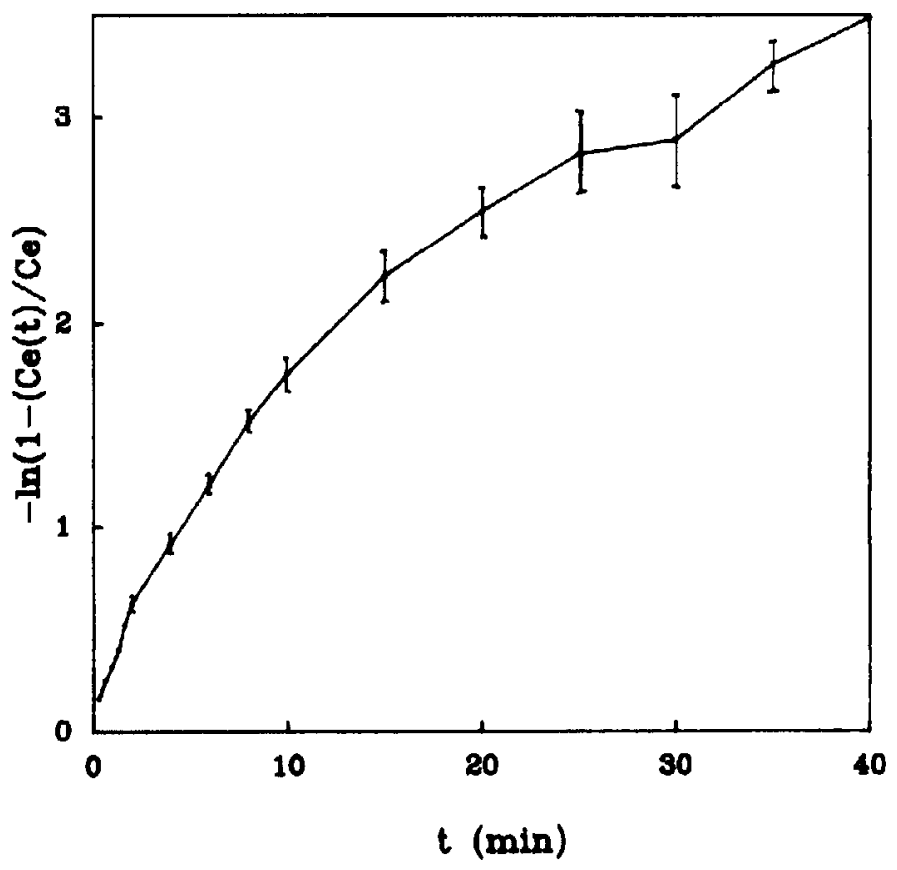

Fig. 1. Ethane efflux vs. time in cherimoya fruit. Bars are SD for five fruit. 
into a rubber stopper. Ethylene production was expressed as nanoliters of ethylene per gram of fresh weight per hour.

Cherimoya fruit surface area was calculated using skin planimetry, and volume was determined by water displacement. From the ethane efflux rate, we calculated $\mathrm{R}$ out of the fruit using the equations noted above.

Cherimoya fruit ripened rapidly during storage at 20C, passing through the preclimacteric, climacteric, and senescent stages in 5 to 6 days (Martinez et al., 1990). The fruit lost weight at the same time due to metabolic processes and water loss. The final weight loss was $\approx 5 \%$ of the initial fruit weight and similar for fruit with or without petroleum jelly on the stem scar (data not shown).

Previous experiments (unpublished) demonstrated that ripeness stage had a marked effect on fruit texture and R. For the present experiments, we took fruit of similar shape, size, and ripeness stage to obtain more uniform results.

A plot of ethane efflux against time (Fig. 1) gave a curve similar to that obtained by Banks (1985) with potato tubers. This approach is not suitable for calculating cherimoya fruit $\mathrm{R}$ because it lacks linearity. The plot for ethane evolution during the first $120 \mathrm{sec}$ (Fig. 2) shows a linear trend with no significant devia-

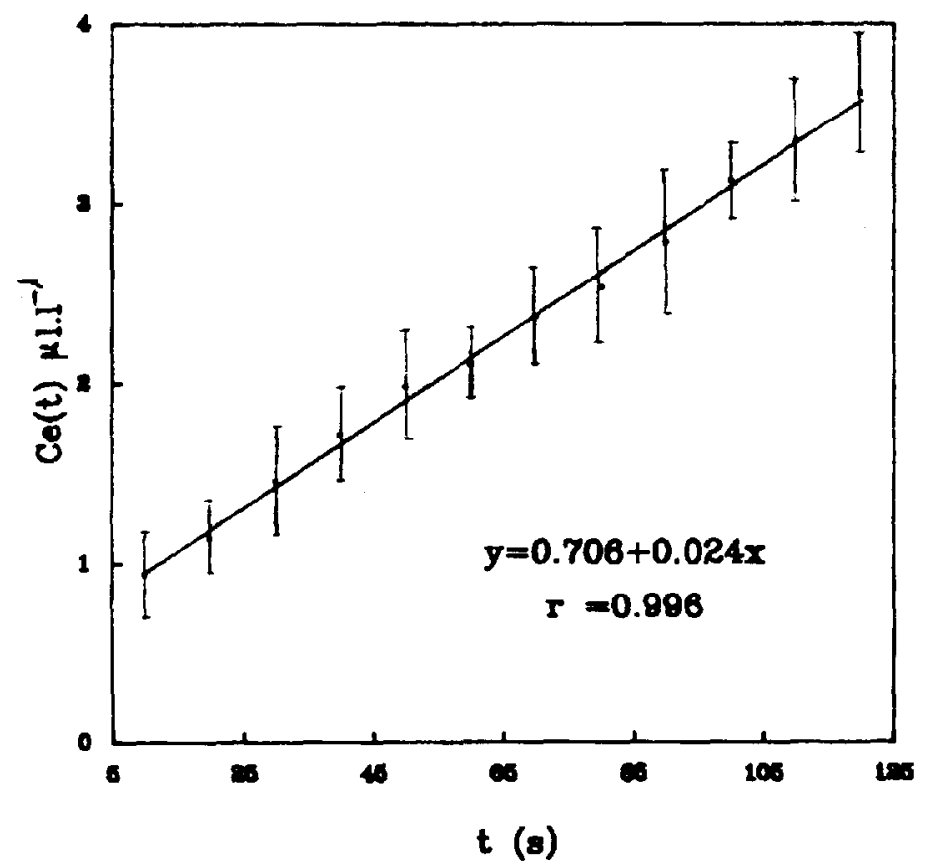

Fig. 2. Changes in ethane concentration in the ambient atmosphere with time. Bars are SD for five fruit.

tions from the regression line. The linear model proposed by Banks (1985) is therefore more suitable than the exponential process (Fig. 1) proposed by Cameron and Yang (1982).

In our experiments, preclimacteric cherimoya fruit (mean surface area of $150.7 \pm 14.2$ $\left.\mathrm{cm}^{2}\right) \mathrm{R}$ was $2048 \pm 167 \mathrm{~s} \cdot \mathrm{cm}^{-1}$.

In subsequent experiments, we studied the changes in $\mathrm{R}$ (ethane) in cherimoya fruit at different ripeness stages-from preclimacteric to senescence-using nontreated fruit and fruit in which the stem scar was covered with petroleum jelly. $\mathrm{R}$ increased markedly as the fruit ripened (Fig. 3). The increase in diffusion may have been caused by a higher epidermal R, possibly due to wax accumulation, or from elevated $\mathrm{R}$ in the intercellular channels caused by reduced free intercellular volume due to flooding with cell sap or loss of cell wall rigidity.

$\mathrm{R}$ increased linearly during ripening in the treated and control fruit (Fig. 3). Higher R values (significant at $P=0.01$ ) were noted in fruit with. petroleum jelly on the stem scar, particularly after day 2 . The rise in $\mathrm{R}$ must reflect an increase in diffusion through the epidermis, as there was no exit through the stem scar since it was blocked with petroleum jelly. As R presents a parallel system similar to electrical circuits (Cameron and Reid, 1982), we can consider that the increase is due more to modifications taking place in the epidermis than to blockage of intercellular channels in the fruit.

The ethylene evolution rate almost tripled between days 1 and 3 and then decreased to near the rate at day 1 , whether or not the stem scar was blocked with petroleum jelly (Fig. 3).

The increase in epidermis $\mathrm{R}$ during ripening created anaerobic conditions in the internal tissues during the advanced ripeness stages, particularly in fruit with petroleum jellycovered stem scars. The latter fruit had the characteristic fermented smell when cut. If,
A

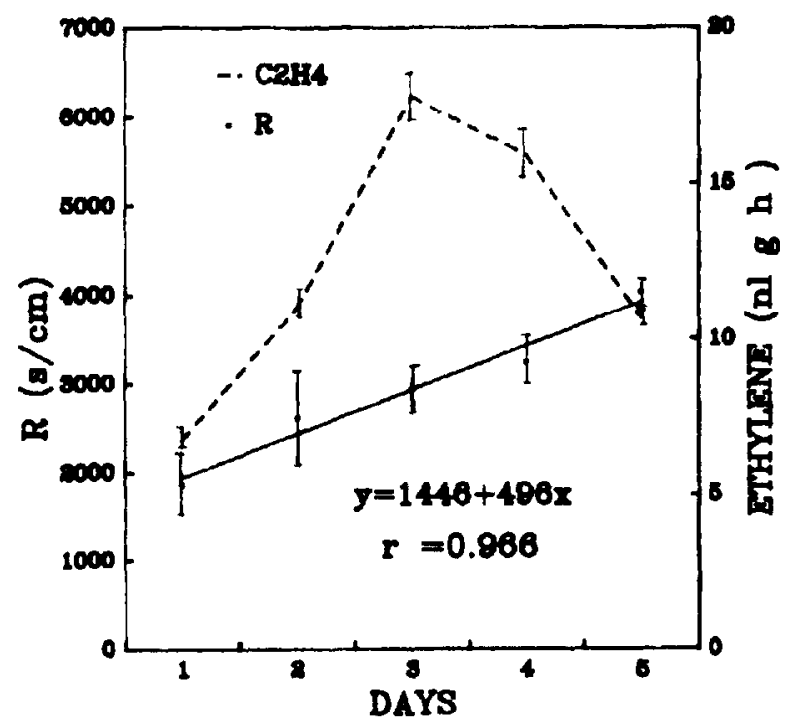

B

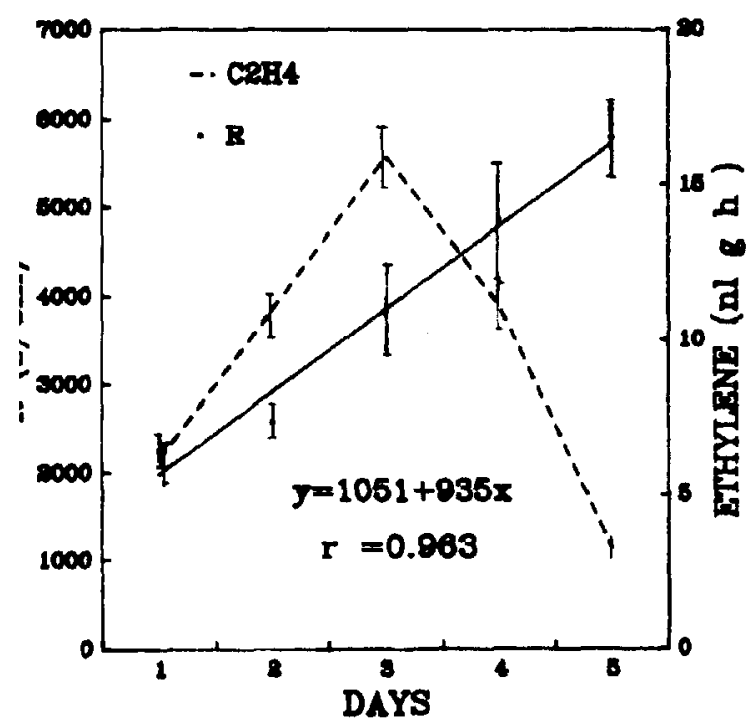

Fig. 3. Changes in resistance to ethane diffusion (-) and ethylene emission rate (---) in cherimoya fruit during ripening. Fruit were harvested at the preclimacteric stage and kept at 20C. (A) Control fruit. (B) Fruit with petroleum jelly-covered stem scars. Bars are sD for five fruit. 
according to the above data, we accept that changes produced in the skin are more important than those in internal cherimoya tissues (flesh) for reduced gas exchange, then some kind of protective system will be needed to decrease dehydration through epidermal tissue oxidation.

\section{Literature Cited}

Banks, N.H. 1985. Estimating skin resistance to gas diffusion apples and potatoes. J. Expt. Bot. 36:1842-1850.

Burg, S.P. and E.A. Burg. 1965. Gas exchange in fruit. Physiol. Plant. 18:870-883.

Burton, W.G. 1978. Biochemical and physiological effects of modified atmospheres and their role in quality maintenance, p. 97-1 10. In: H.O. Hultin and M. Milner (eds.). Postharvest biology and biotechnology. Food and Nutrition Press, West Port, Conn.

Cameron, A.C. and M.S. Reid. 1982. Diffusive resistance: Importance and measurement in controlledatmosphere storage, p. 171-180. In: D.G. Richardson and M. Meheriuk (eds.). Controlled atmospheres for the storage and transport of perishable agricultural commodities. Timber Press, Beaverton, Ore.

Cameron, A.C. and SF. Yang. 1982. A simple method for the determination of resistance to gas diffusion in plant organs. Plant Physiol. 70:21-23.

Kuo, S. and K.L. Parkin. 1989. Chilling injury in cucumbers (Cucumis sativa, L.) associated with lipid peroxidation as measured by ethane evolution. J. Food Sci. 54(6):1488-1491.

Martinez, G., M. Serrano, F. Riquelme, and F. Romojaro. 1990. Maduración post-recolección de la chirimoya (Annona cherimola, Mill). II Simposio National Sobre Maduración y Postrecolección de frutos y hortalizas. Lérida 1:4247.

Salveit, M.E. 1982. Procedures for extracting and analyzing internal gas samples from plant tissues by gas chromatography. HortScience 17:878-881.

Sherz, H., G. Kloos, and F. Senser. 1986. Food composition and nutrition tables 1986-87. WissenschaftlicheVerlagsgesellschaftmbH, Stuttgart.

Solomos, T. 1987. Principles of gas exchange in bulky plant tissues. HortScience 22:766-771. 